R95-6

INFORMAL CREDIT MARKETS AND

ECONOMIC DEVELOPMENT IN TAIWAN

by

Shui-Yan Tang

World Development 23(5) (1995): 845-855.

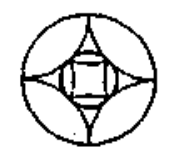

Workshop in Political Theory and Policy Analysis

Indiana University, 513 North Park, Bloomington, Indiana 47408-3895 U.S.A.

Tel. 812-855-0441 - FAX 812-855-3150 - Internet: workshop@indiana.edu 


\title{
Informal Credit Markets and Economic Development in Taiwan
}

\author{
SHUI-YAN TANG* \\ University of Southern California, Los Angeles, U.S.A.
}

\begin{abstract}
Summary. - Taiwan is a case which shows how informal credit markets help to compensate for the limitations of the formal financial system, especially in satisfying the needs of medium and small enterprises. Government regulations and policies affect the way participants in informal credit markets solve selection, enforcement, and incentive problems. Recent changes demonstrate the continued resilience and relevance of informal credit markets during a process of financial liberalization.
\end{abstract}

\section{INTRODUCTION}

Recent debates about the East Asian Newly Industrialized Countries (NICs) center around the relative importance of state guidance versus market mechanisms in economic development. An emerging theme from these debates is that governments in these countries have been actively involved in governing and directing markets and, by so doing, have contributed to their rapid economic growth (Amsden, 1989; Islam, 1992; Wade, 1990). The achievement of these NIC governments contrasts with the failure of many Latin American governments whose economic policies were strongly influenced by rent-seeking activities of various interest groups (Haggard, 1990; Gereffi and Wyman, 1990). A major focus of the recent literature has been to examine the institutional, political, and historical factors that enabled and motivated government leaders in the East Asian NICs to adopt measures that enhanced capital accumulation, efficient resource allocation, and productivity change (Amsden, 1994; World Bank, 1993).

While much of this literature focuses on the part of an economy that is directly regulated by government legislation and policies, relatively little of it systematically examines the informal sector's contributions to the development process. ${ }^{1}$ Such neglect contradicts conventional wisdom about the region. In a recent issue of The Economist, for example, a Taiwanese banker was quoted as saying that 'Taiwan's economic miracle is built on illegal businesses." ${ }^{2}$ One form of such "illegal" or "extra-legal" businesses is Taiwan's informal credit markets, which are estimated to have provided more than one-third of the total amount of loans to private enterprises in the country. Is there any validity to the conventional wisdom about the informal sector? If so. how can it be reconciled with scholarly concentration on formal political and economic institutions?

Although not prominently featured in the East Asian development literature, the informal sector has recently gained increased recognition in the general literature on development (Chickering and Salahdine, 1991; Jenkins, 1988; Roemer and Jones, 1991). Among the most prominent is de Soto's The Other Path (1989), in which he argued that numerous business transactions in Peru had been conducted outside the formal legal framework. The informal sector played an important role in supporting a wide variety of economic activities, including housing, commerce, transport, and industrial production. Some $39 \%$ of the 1984 GDP in Peru was produced and $61 \%$ of all work hours were spent in the informal sector (de Soto, 1988). The informal sector has become an important source of entrepreneurship in Peru. Its pervasiveness, according to de Soto, had mostly resulted from the inefficiency of the larger legal and political institu-

-Numerous individuals and organizations have helped me in preparing this paper. While it is impossible to mention all their names here, I wish to acknowledge, in particular, the help by Vivian Chen. Anita Chou, Richard Chou, Li-Chun Chiang, Jen-Hui Hsu. Jong-Hun Huang, Thomas Huang, JiaDong Shea, and Yung-Nane Yang. Gerald Caiden, Ami Doshi, Don Fuller, Peter Robertson, Robert Stallings, and two anonymous reviewers provided useful comments on an earlier version of the paper, which was presented at the Workshop on the 20th Anniversary of the Workshop in Political Theory and Policy Analysis, Bloomington, Indiana, June, 1994. Financial support from the Pacific Cultural Foundation is gratefully acknowledged. Final revision accepted: December 10, 1994. 
tions. The informal sector had compensated for the inadequacy and restrictiveness of the formal sector.

The Peruvian experience poses an interesting question about the role of the informal sector in East Asian development. Since government institutions and policies in the East Asian NICs are considered by many scholars as relatively efficient and supportive of productive business transactions, is the sizable informal sector in these countries performing essential functions that cannot be adequately handled through formal institutional channels? Or are some aspects of the formal institutions in these countries less efficient than are generally assumed, and, as a result, the informal sector plays an important role in compensating for the formal sector's inadequacy? This paper examines some of these issues by studying Taiwan's informal credit markets whose sizes and operations are relatively well documented, especially in Chinese sources. ${ }^{3}$ Defined as credit transactions that operate outside government control and regulation, as in contrast to the regulated money market and the formal banking system, informal credit markets exist in various forms - rotating credit associations, trade credit, indigenous banking, etc. The paper first explores several general issues about the economic role of informal credit markets in developing countries. Then it looks closer at some salient features of the informal credit markets in Taiwan and how they are affected by various government regulations and policies. It concludes by discussing the theoretical and practical implications of Taiwan's experience.

\section{THE ECONOMIC ROLE OF INFORMAL CREDIT MARKETS}

A major economic problem in developing countries is financial intermediation - the mobilization of capital from one group (savers/lenders) and its simultaneous allocation to meet the needs of another group (borrowers/entrepreneurs) (Christensen, 1993). Critical for efficient capital mobilization and allocation, financial intermediation can be performed through various forms of instruments, the three most important ones being equities (stocks), long-term loans (bonds), and short-term loans (credit) (Stiglitz, 1989b). In most developing countries, because of the relative underdevelopment of the first two forms of instruments, credit markets for short-term loans become the major means of financial intermediation.

The capital mobilization function of credit markets is, however, constrained by several factors. First, when there is a lack of macroeconomic and monetary stabilities, as experienced by many Latin American countries during the $70 \mathrm{~s}$ and $80 \mathrm{~s}$, people prefer to invest in fixed assets - real estate, jewelry, etc. - or to save in foreign currencies overseas, instead of depositing local currencies in domestic institutions.
Second, savers are willing to deposit money in a saving institution only if they believe that they will be able to withdraw the money according to prespecified terms. The risk of bank closure and the availability of deposit insurance become important considerations for potential depositors. In many countries, governments establish banking regulations such as capital and reserve requirements to ensure the ability of banks to meet withdrawal demands. Third, government regulation creates opportunities for political abuses. In some developing countries, for example, the formal banking system is tightly controlled by government officials who see it as a convenient source of cheap credit for their own expenditure projects and their favored political clients (Hanke and Walters. 1991). Offering mostly negative real interest rates to depositors, the banking system is not an attractive saving avenue for most people (Fry, 1988; McKinnon, 1973). The limitation of the formal banking system may be compensated by informal credit arrangements that offer higher returns for depositors, but these informal arrangements are usually limited in scale and lack legal protection for depositors.

In addition to overcoming obstacles for capital mobilization, credit markets need to overcome information problems associated with credit allocation (Stiglitz, 1989b). First, because of the potential for default, lenders need to solve the selection problem screening loan applications based not just on how much interest they are willing to pay. but on their probability of default. Second, enforcement problems concern the ability of lenders to ensure that principals and interests will actually be repaid by borrowers at specified times. Third, loan contracts need to include a variety of provisions other than interest rates. Nonprice terms such as collateral and other kinds of restrictive covenants, such as market interlinkage", are often needed to create appropriate incentives for loan repayment.

Various forms of credit markets tackle these problems differently. Faced with a wide array of potential borrowers, the formal banking system tends to tackle the selection and enforcement problems by making these borrowers homogeneous, for example, by imposing stringent collateral requirements or by requiring borrowers to provide carefully documented evidence showing their intention and ability for repayment (Floro and Yotopoulos, 1991). The efficiency of the formal banking system in credit allocation is enhanced if the legal framework makes collateral agreements enforceable at low costs. Other institutional infrastructures such as reliable public accounting systems and credit reporting services can also make credit allocation through the banking system more efficient. The efficiency of the formal banking system in many developing countries can be improved by strengthening these basic legal and institutional infrastructures. 
No matter how efficient the legal infrastructures, the formal banking system can only cater to the needs of a limited portion of the population, i.e.. enterprises or individuals who can provide collateral or documented credit references. Credit needs of the poor and many small entrepreneurs will remain unsatisfied through the formal banking system. These people mostly are unable to provide collateral, or the loans they need are so small that administrative costs for lenders outweigh expected returns. While small borrowers generally encounter difficulties in obtaining credit from formal financial institutions in developed economies, those in developing economies face even greater obstacles because banking systems in these economies tend to be more rigid and small firms generally lack accounting records.

This characteristic of credit markets creates serious problems for policy makers in countries in which small enterprises play an important role in economic development. A common prescription in many developing countries has been for governments to develop concessional credit programs to help farmers, small enterprises, and start-up companies. These programs, however, are faced with formidable problems insolvency due to high default rates, failure to deliver credit to targeted groups, administrative inefficiency, etc. (Adams and Pischke, 1992; Braverman and Guasch, 1993).

Many of the attempts by governments and international donors to increase the supply of finance to the noncorporate sector have focused on providing access to affordable credit. They have foundered because they did not take into account the true costs and risks of lending to the sector (World Bank. 1990, p. 100).

In many developing countries, informal credit markets play an important role in solving allocation problems associated with individuals, fanners, and small enterprises. Because of the absence of direct government regulations, informal credit markets are usually characterized by flexibility of operation. Various arrangements are developed by participants to deal with specific information problems associated with different transactions (Adams and Fitchett, 1992; Floro and Yotopoulos, 1991). By utilizing such mechanisms as social networks and market interlinkage, informal credit arrangements can reduce many selection, enforcement, and incentive problems inherent in credit transactions which, otherwise, may not be effectively handled in formal financial institutions. It is well documented, for example, that informal moneylenders, who utilize personal ties to facilitate contract enforcement, can potentially provide an important service to rural people who lack tangible collateral for securing loans from the banking system (Adams and Fitchett, 1992). In both rural and urban areas, trade credit is based on market interlinkage, in which credit is linked to borrowers' behaviors in other transactions. Such interlinkage increases lenders' ability to monitor borrowers' behaviors; it also motivates borrowers to repay loans by making other transactions contingent upon loan repayment. Trade credit is critical for the survival of many small and medium enterprises in developing countries (Ghate, 1992).

While informal credit markets play an essential financial intermediation function in many developing countries, they are also subject to various limitations. Participants in informal credit markets frequently operate illegally and are subject to severe penalties. The operation of these markets tends to be limited and secretive and sometimes involves bribes and kickbacks to government officials (Hanke and Walters, 1990). These markets tend to be highly segmented, with participants limited to only those with personal relations with one another. Since transactions are mostly undertaken without legal protection, participants are vulnerable to potential losses and abuses. With transactions confined mostly to specific social circles, risk diversification is often limited. To reduce default risk in the absence of tangible collateral, informal loans tend to be small and short term. This raises the transaction costs. Because loans usually come from lenders' equity instead of third-party deposits, the money creation function of the informal credit market is limited (Christensen, 1993). In transitional societies where old social relations and networks have broken down before new institutions are established, no effective informal credit market may exist.

Despite the recognition of both the potential and limitations of informal credit markets in developing countries, many policy issues remain unsolved. Among the most important is how government policies affect the operation of informal credit arrangements. Should a government try to support or to eliminate informal credit markets? How would financial sector reform affect the role of informal credit markets in financial intermediation? Many scholars argue that some informal credit markets may be locally efficient, and ill-conceived government interventions may undermine an otherwise efficient local market (Floro and Yotopoulos, 1991). In developed and developing economies alike, private money lenders face problems of contract enforcement and of screening and monitoring borrowers. If government intervenes, it will face the same problems, though maybe in slightly different forms than would the private moneylender. While government interventions may help to reduce enforcement problems in credit transactions, these options need to be used selectively. Adverse selection and monitoring difficulties, for example, may undermine a government's attempt to provide subsidized credit to poor farmers through direct administrative means. As argued by Stiglitz (1989a, p. 202): 
It may be foolhardy for the government to go where the private market fears to tread: credit rationing in private capital markets does not necessarily suggest a role for government providing credit. It may, indeed, be at a disadvantageous position both in screening applicants and monitoring loans (ignoring the obvious political economy problems to which government loan programs can give rise, particularly in highly inflationary situations).

Under certain circumstances, informal credit arrangements may be more effective in solving selection, enforcement, and incentive problems in credit transactions

Although not directly sanctioned by government, informal credit transactions are not undertaken in an institutional vacuum. Most of these transactions are governed by customary rules among participants. If effectively enforced, these rules facilitate transactions by reducing selection, enforcement, and incentive problems among participants. While some of these rules are parts of traditional social practices and conventions, others are adaptations or reactions to existing legal, political, and economic constraints. As argued by Chandavarkar (1992), it is useful to distinguish between two components of the informal financial sector - the "autonomous" and the "reactive" components. The former refers to traditional financial arrangements that predated the formal sector in modern times (e.g., indigenous banking and rotating credit associations). The latter refers to informal financial arrangements that developed in response to the restrictions, or deficiencies, inherent in the formal sector (e.g., underground finance companies). This "reactive" component often expands and contracts in response to cycles of repression and liberalization in the formal financial sector. While, in reality, many informal credit arrangements consist of both of these components, Chandavarkar's argument underscores the multiple factors that affect the development of these arrangements.

\section{INFORMAL CREDIT MARKETS IN TAIWAN}

Taiwan is a case of how informal credit markets help to compensate for the limitations of the formal financial system, especially in regard to satisfying the credit needs of small enterprises. Instead of competing directly with each other, the formal and informal sectors have largely complemented each other in solving crucial financial intermediation problems in Taiwan's development process. The experience of Taiwan also illustrates that informal credit markets do not operate in an institutional vacuum; government regulations and policies affect the way participants in informal credit markets solve problems in selection, enforcement, and incentive. Furthermore, recent changes in Taiwan demonstrate the continued resilience and relevance of informal credit markets during a process of financial liberalization.

(a)

\section{Complementarity between formal and informal} credit markets

In Taiwan, small and medium enterprises play an important role in its export-driven development strategy. In 1985, for example, small and medium enterprises (those with fewer than 300 employees) contributed about $50 \%$ of value added and employed $62 \%$ of the workforce in Taiwan. These enterprises also produced $65 \%$ of total export value in the same year (Biggs. 1991, p. 169). These small and medium firms form extensive subcontracting networks among themselves and with larger enterprises. Such an industrial structure enables the economy to compete internationally by focusing on exporting products based on intermediate technology (such as electronics components for machinery) that is characterized by high volatility and the need for rapid adaptation to change.

The banking system in Taiwan, which until recently has been mostly government owned, mainly serves the needs of public enterprises and large-scale private enterprises. The government-controlled banking system has supported export-oriented industries by providing large companies in those industries with additional and concessional credit (Wade, 1990). The banking system, however, has been unresponsive to the credit needs of small and medium enterprises. By examining the distribution of loans from formal financial institutions. Shea and Kuo (1984) and Shea (1990) found that productivity, profitability, and growth potential of industries had little effect on credit rationing decisions. During 1965-82, five times more bank credit per dollar of sales went to large firms than small ones, and four times more credit per unit of value added went to large firms (Shea and Kuo, 1984). According to annual surveys conducted by the Central Bank during 1964-90, private enterprises borrowed an average of $35 \%$ from outside formal financial institutions (Shea, 1992, p. 3). Among private enterprises, the smaller their scale, the larger the proportion of their loans came from informal credit markets. According to a survey conducted by the Central Bank in 1983, private firms with assets of one to five million NT dollars received $68.9 \%$ of their domestic borrowings from informal credit markets; those with 40-100 million received $39.7 \%$; and those over 1,000 million received $10.3 \%$ (Shea, 1992).

The informal credit market from which enterprises obtain their loans exists in many forms. One of them is trade credit. As a popular form of informal credit in many countries, trade credit utilizes information links between parties that have developed over time through contracting arrangements or commodity transactions (Ghate, 1992, p. 31). In Taiwan, trade 
credit between enterprises mostly exists in the form of "supplier's credit." i.e.. loans from supplying firms to buying firms (Wade. 1990). It also exists in the form of "upstream" firms providing loans to "downstream" contractors (Biggs. 1991). In many cases, larger firms obtain funds from the formal banking system, and then extend loans at substantially higher interest rates to smaller firms with which they have ongoing business relationships. ${ }^{5}$

While relying heavily on external debt financing, private enterprises also rely on internal sources, which accounted for around $45-55 \%$ of total private enterprise investment in the past three decades. Internal financing was even higher among smaller firms, amounting to $60-65 \%$ (Biggs, 1991. p. 178). Although it is difficult to estimate how much of these internal sources came from personal or family savings, it is likely that a good portion came from rotating credit associations among relatives and friends. While these associations vary in format, the general principle is similar. For example, a group of, say, 10 individuals makes an agreement that each individual contributes a sum of money to form a pool every month. Each month, through a bidding process, one individual receives the pool. In this way, those who need money more than others can receive a pool of money and promise to pay a certain interest on a monthly basis. The same process goes on for another nine months, and each month those who have yet to receive a pool of money earlier in the process and those who do not need it can wait until later in the process and earn interest from others in the group. ${ }^{6}$ Two general household surveys conducted around 1980 indicated high participation rates in these associations, one indicating $85 \%$ and the other $68 \%$ (Peng and Chang, 1985, p. 188). According to a recent survey, the participation rate among business people was even higher, at $95 \%$ (Chen, 1993, p. 37). Furthermore, based on two household surveys in 1978 and 1981 respectively, it is estimated that the volume of funds that were processed through rotating credit associations fell within the range of 2.7 to $6.8 \%$ of GNP annually (Peng and Chang, 1985, p. 188). Rotating credit associations appear to have been a major means of raising capital to start a small business.

Besides trade credit and rotating credit associations, there is a wide array of other informal credit arrangements. One major form is underground bankers who conduct bank-like businesses including deposit-taking and lending, but without a proper license. Such underground bankers offer loans at higher interest rates (usually several times regular bank rates). Although charging higher interest rates, these bankers serve a useful function by providing short-term loans to most people in a speedy manner (Huang, 1983). Another form of informal credit arrangement involves firms accepting deposits from their own employees. Such deposits serve as a form of liquid capital for the firm and are consìdered as a personal loan from employees to firm. Since the late 1970s, there has emerged an increasing number of leasing companies that financed the purchase or leasing of heavy equipment and machinery by small and medium firms. The total amount of financing through these companies increased from 0.7 billion NT dollars in 1977 to 17.7 billion in 1983 (Peng and Chang, 1985). Many of these companies were associated with large manufacturing firms and their capital was mostly borrowed from banks. These companies served as a financial conduit between the banking system and small and medium firms. ${ }^{7}$

Taiwan's experience with informal credit markets is not unique. As indicated in many recent studies, formal and informal credit systems coexist in most countries worldwide (Ghate, 1992; Adams and Fitchett, 1992; Hoff, Braverman and Stiglitz, 1993). In Taiwan, maybe more than many other developing countries, the formal and informal credit markets complement each other in solving crucial development problems. As argued by Wade (1990), the highly regulated financial system has enabled the Taiwanese government to limit private economic power, to channel funds to industrial production, and to implement conservative monetary policy and inflation control. Rigid government regulations, together with the inherent information problems associated with small-scale credit transactions, made it difficult for innovative, small enterprises to secure loans from the formal banking system. Informal credit markets compensate for this limitation of the formal sector by catering to the credit needs of these small companies.'

While informal credit markets contribute to financial intermediation, it is also necessary to understand their limitations and potential problems. In fact, most of the Chinese sources on the subject emphasize problems associated with informal credit markets. There are frequently reports of innocent people being victimized by malpractice in informal credit markets. In the early 1980 s, for example, there were a number of well-known cases in which organizers of rotating credit associations defaulted on members for millions of dollars (Chen, 1993; Lin, 1991; Shen, 1984). Government authorities were, on occasion, under social pressure to deal with manifest problems or abuses in the informal credit market. While serving an important financial function, informal credit markets are not foolproof.

\section{(b) Government regulations and informal credit markets}

The Taiwanese government's attitude toward informal credit markets can be characterized as a form of benign neglect. While some forms of informal credit 
arrangements such as underground banking are outlawed, the government appears to be neutral about other forms such as rotating credit associations. Transactions in rotating credit associations have been considered to be based on private contracts among participants. Such contracts have not been prohibited by the law. Indeed, the government has recently initiated legislative change to the Civil Code to include provisions about the rights and duties of participants in rotating credit associations (Chen, 1993, p. 37). For the outlawed component of the informal market, the Ministry of Finance and the Bureau of Investigation in the Ministry of Justice are responsible for investigating and prosecuting illegal operations. Except during periods in which financial scams became major public concerns, as in the late 1980s, these agencies appeared to lack the resolve to clamp down on illegal financial practices. Court action was taken mostly to deal with open grievances from the parties involved (Lin, 1991; Shen, 1984). It is also interesting to note that the Economic Research Department of the Central Bank publishes interest rates in informal credit markets on a monthly basis. Usually two or three times the regular bank rates, these informal interest rates are used by Central Bank officials as a reference for setting official interest rates. The Economic Research Department of the Central Bank also includes in its annual survey of Flow of Funds in Taiwan District the volume of informal financial transactions. Furthermore, multiple pages of classified advertisements on informal credit appear daily on major newspapers and are tolerated by government authorities.

The Negotiable Instruments Law enacted in the 1950s has facilitated formal credit transactions. According to the Law, it is a criminal offense to fail to honor postdated checks. The legal liability is shared by both the issuer and all additional endorsers. Banks are legally obligated to report violations to the authorities. Because of this law, banks limited the number of blank checks available to customers. Such legal protection enabled the postdated check to become a widely used credit instrument in the informal credit market. When a person borrows from an underground banker and lacks sufficient real estate, stocks, or other valuables as collateral, a common practice is to have the person write three checks - the first posting the loan amount plus interest, the second posting two to three times of the loan amount, and the third blank. If the lender is unable to cash the first check on the specified date, he or she could submit the second one or the third one with any amount he or she writes in. The issuer is liable for criminal prosecution after three bounced checks. Because of the legal sanction associated with the postdated check, it is known that underground bankers often preferred it to such collateral as real estate and stocks which may require complicated legal procedures to process (Shen, 1984).
The postdated check is also a major instrument in trade credit transactions. A common method is for purchasers to issue a postdated check (posting the product price plus interest and the payment date) in favor of suppliers (Briggs, 1991. pp. 184-185). When suppliers have accumulated large numbers of postdated checks and need cash, they can endorse the check and use it as collateral to secure a loan from another party. A discounting market for postdated checks, similar to the regulated money market, has emerged. Sometimes a postdated check can be endorsed by several people and discounted many times. Because of the information costs involved, the market for postdated checks is highly segmented checks are traded mostly among people in the same industry who know one another well.

The postdated check system has become so important to business transactions that the government has on occasion, intervened to maintain its stability. In 1985 , for example, the government initiated a temporary program that allowed major industries and enterprises a six-month grace period for redeeming bad checks without criminal prosecution (Biggs, 1991).

While the legal status of postdated checks has facilitated informal credit transactions, it has also been critized (Effros, 1971). One major criticism is that the enforcement of the Negotiable Instruments Law had preoccupied much of the criminal justice system. According to Biggs (1991, p. 182), the majority of the criminal cases that went through the court system in the 1970s were related to that particular law. There are also well-known cases in which underground bankers used potential criminal prosecution to threaten and extract additional compensation from borrowers who had used postdated checks as collateral. In these cases, a legal means is employed to support illegal and unfair practices (see Shen, 1984, p. 18). Sometimes, innocent people were penalized and the crooks fled as in cases when a husband had used his wife's name chop to write bad checks and left her behind to face criminal prosecution (Wade, 1990, p. 163). ${ }^{9}$ All these problems had exerted pressure on the government to reform the Negotiable Instruments Law. After substantial efforts in building a regulated money market from the late 1970s (Emery, 1991), the government finally abolished the criminal penalty associated with postdated checks in 1987. While this legislative change helps to prevent some of the above-mentioned problems, postdated checks remain a common instrument in informal credit transactions. Bad checks are still subject to sanctions by individual banks. In the Financial Statistics Monthly published by the Central Bank, market interest rates for unsecured loans are still listed separately from those that are backed by postdated checks. Yet interest rate differentials between the two types of loans have become minimal. In February 1993, for instance, the average monthly interest rate in Taipei for loans against postdated 
checks was 1.95 as compared with 2.00 for unsecured loans.

Besides specific policies toward informal credit transactions, other policies also have indirect effects on the informal financial market. As mentioned earlier, the banking system in Taiwan has been unresponsive to the credit needs of small firms. This is partly due to the inherent difficulties for banks in overcoming the selection, enforcement, and incentive problems associated with lending to borrowers who lack collateral and accounting records. The tendency to be unresponsive to small firms is exacerbated by an institutional feature of the banking system. Until 1992, the government of Taiwan directly owned and managed most of the domestic banks. These banks are subject to numerous accounting, budgeting, personnel, and auditing restrictions characteristic of government bureaucracies. State-owned banks are under the supervision of 15 agencies in the central and provincial governments (Cheng, 1993, p. 80). Loans from these banks are treated as government assets by auditing agencies which are reluctant to write off bad loans. Because they may be legally liable for loan defaults, bank officials emphasize collateral as the major criterion for loan decisions (Shea, 1992).

Lax disclosure regulations and practices in Taiwan also make it difficult for banks to collect information about medium and small firms. Most companies, especially medium and small, lack accurate financial statements, a practice encouraged by the tax code that allows companies without complete accounting records to use the average rate of the specific industry as a base to calculate taxes. Even though it is legally required, about $72 \%$ of all registered companies in 1980 failed to file financial statements with the Ministry of Economic Affairs (Chen, 1993, p. 81). The public accounting system is generally considered unreliable. These conditions make it extremely difficult for banks to determine the creditworthiness of most companies that lack tangible collateral. These, together with the conservative orientation of bank officials, have made the informal credit market more important in satisfying credit needs of small enterprises.

Finally, Taiwan's relatively stable fiscal environment has contributed to the strength of informal credit markets. One major political-economic problem confronting many developing countries, especially those in Latin America, has been the national government's inability to create a stable fiscal environment. With unstable price levels and often negative real interest rates in the formal banking system, individuals want to invest primarily in nonproductive assets such as precious metals and real estate, or to divert their wealth abroad. In Taiwan, throughout most of the postwar period, the national government has maintained restrictions on citizens transferring money abroad, restrictions on land speculation, and conserv- ative government spending and fiscal policies (Ranis and Mahmood, 1992; Wade, 1990). These policies have helped to create a favorable macroeconomic structure that encourages citizens to save in the nation's own monetary units. While the formal banking system offers lower interest rates than the informal sector, deposits are virtually guaranteed because of the public ownership of most banks. For people who seek a higher return on their savings, the informal credit market offers a riskier but viable alternative. All these factors have provided a supportive environment for people to invest in the informal credit market.

\section{(c) Financial sector reform and informal credit markets}

While the limitation of the formal financial system has partly been compensated by the flexibility of informal credit markets, major pressures have built up since the 1980s for the Taiwanese government to reform its formal financial system. First, internationalization of finance has become a major trend worldwide since the mid 1980s (The Economist. 1992). It has become more and more counterproductive for countries to try to limit the flow of international capital. In response, the Taiwanese government has considerably lessened restrictions on capital flow in and out of the country in recent years. Unless Taiwan can develop a competitive financial system that can efficiently handle large capital transactions, its economy will be disadvantaged in the international market.

Second, the rapid economic growth and conservative government spending policies in the past few decades have enabled the central government to accumulate large amounts of cash reserve. It has become increasingly evident that the rigid financial system has encountered difficulties in allocating excess capital to productive uses. It is, for example, estimated that $40 \%$ of bank deposits remained idle in 1987 (Cheng, 1993, p. 90).

Third, the underdeveloped financial and capital markets appear to be incapable of satisfying the investment needs of people who have accumulated increasing amounts of wealth. One result is an increasing number of scandals associated with underground investment companies during the second half of the 1980s. During this period, instead of being satisfied with putting money in the banking system or such traditional credit arrangements as rotating credit associations, increasing numbers of people put money into underground investment companies that emerged after 1985. Promising investors unrealistically high rates of return, these companies were engaged in real estate and stock market speculations and varieties of financial scam (Lin, 1991). These companies mostly operated in violation of government securities laws and were engaged in financial transactions beyond 
what is usually considered part of the informal credit market. According to one estimate, these companies had attracted around NT \$200-300 billion of investment by 1989 , which was $15-23 \%$ of the year's national budget (Cheng, 1993. p. 85). The subsequent failure of an increasing number of these companies finally compelled the government to close them down in 1989. Such an episode further confirmed the need to reform the financial system.

Fourth, a rigid financial system was used by Kuomintang, the ruling party, as a means to prevent large concentrations of capital in the hands of individuals or groups who might turn out to challenge the party's authority, as was the case during the 1930s and 1940s in mainland China (Hamilton and Biggart, 1988). With the increasing democratization of the political system, such a consideration has become less important for the political leadership. The leadership has become more willing to embrace financial liberalization.

The question nowadays is no longer whether to reform the financial system or not, but how to reform it. Experience in Taiwan shows that informal credit markets play a critical role in the reform process. Since the late 1970s, the government has begun to encourage the development of a regulated money market. Such an effort seems to have decreased enterprises' credit demand on the informal credit market. The share of private enterprises borrowing from the informal market decreased from around $36 \%$ in 1978 to around $30 \%$ in 1984. The share, however, went up in 1985 and 1986 (at 35 and $40 \%$ respectively), until it began to go down again after 1987 reaching $24 \%$ inl990. ${ }^{10}$ Some scholars attribute the temporary jump in 1985 and 1986 to the government's effort to lift restrictions on bank interest rates starting the early 1980s (Shea, 1992; Shea and Yen, 1991). In 1985, the government further broadened the range in which banks could set their lending rates. This change, however, was implemented at a time when most banks were still government owned and run according to rigid bureaucratic guidelines. A combination of higher interest rates and continuing conservatism of the banking system might have turned more enterprises from the formal banking system to the informal credit market during the period.

It is likely that the introduction of $\mathbf{1 5}$ new private banks in 1992 and subsequent privatization of government-owned banks will eventually make the formal financial system more competitive and responsive to the needs of small and medium enterprises. Nevertheless, it is unlikely that the reformed financial system will totally eliminate the function of the informal credit market, which is likely to remain a viable source of credit for individuals and smaller firms that need short-term credit but lack collateral and credit records. At present, major newspapers are still filled with pages of advertisements for informal loans. In 1991, the informal credit market still constituted about
$25 \%$ of all financial transactions." Interest rate differentials between informal loans and bank loans remain substantial. In February 1993. for instance, the average annual interest rate for informal loans against postdated checks was 26.08 as compared with the prime rates charged by domestic banks that ranged from 7.875 to $10.500 .^{12}$ Yet current differentials have slightly decreased in comparison with those in the mid1970 s and early 1980s, during which interest rate differentials between general (short-term) bank loans and informal loans against postdated checks averaged about $20 \%$ (Biggs, 1991).

\section{DISCUSSION AND CONCLUSION}

Formal credit markets in both developed and developing countries tend to favor large firms in credit allocation. Such a phenomenon is especially pronounced in Taiwan where public enterprises and large private firms receive the lion's share of credit from the formal sector, and medium and small firms obtain most of their credit from the informal sector. Such market segmentation was interpreted by some scholars as evidence of "financial repression" in which governments impose unnecessarily restrictive regulations on the formal financial sector. While valid to a certain extent, such a view neglects the transaction costs associated with the allocation of credit. From the transaction-cost perspective, credit allocation is subject to various selection, enforcement, and incentive problems. In catering to the credit needs of smaller firms that lack collateral and a documented credit record, the informal sector may have a comparative advantage over the formal sector by virtue of its ability to utilize social networks and market interlinkage to solve various transaction problems. In Taiwan, the informal sector performs a complementary function by filling the gap left by credit rationing in the formal sector. This complementary function of informal credit is especially important given Taiwan's heavy reliance on small and medium enterprises as a major engine of economic growth.

While informal credit can help to fill the gap left by the formal sector, it does not mean that informal credit is foolproof. Informal financial transactions are subject to various limitations and potential abuses. Taiwan's recent experience with underground investment companies, for example, demonstrates the need for governments to help provide reliable institutional channels for investment once people have accumulated substantial wealth. The challenge facing Taiwan and many other developing countries nowadays is to develop enabling legal frameworks that facilitate efficient transactions in both the formal and informal sectors.

Indeed, Taiwan's own experience shows that legal rules and other public institutions affect credit transactions in both sectors. The Negotiable Instruments 
Law. for example, had for many years facilitated the operation of informal credit markets. The government's failure to help develop a reliable public accounting system has made it difficult for formal credit institutions to collect information about medium and small firms, and such a failure has indirectly encouraged the use of informal credit among those firms. To strengthen the role of the formal sector in financial intermediation in Taiwan, it is insufficient just to lift restrictions on interest rates and to allow for the opening of new private banks. The development of institutional infrastructure that facilitates information flow and contract enforcement is needed to help the formal sector overcome various credit transaction problems. In this regard, a more credible public accounting system is one form of institutional infrastructure Taiwan needs to develop.

This article supplements the recent political economy literature on the East Asian NICs which emphasizes government's leadership in economic development. While government policies in Taiwan have had major impacts on informal credit markets' mode of operation, these markets also operate in ways that are beyond direct government control. This shows that important social and economic institutions are not only those that are sanctioned by government authorities. Many informal social and economic arrangements play an important role in facilitating economic transactions. The comparative advantage of a nation involves not just human and natural resources, but also the "social capital" (Coleman, 1993) embedded in these informal institutions. By complementing formal institutions, the informal sector can play a significant role in economic development. Instead of viewing the informal sector as purely a symptom of underdevelopment, future research on East Asia needs to examine how different configurations of formal and informal institutions affect developmental processes, how government regulations and policies affect the operation of the informal sector, and how the informal sector responds to economic reform processes.

\section{NOTES}

1. As pointed out by a reviewer, some studies exist on the empirical level for almost every country in the region, but the informal sector is largely ignored in the general analysis of East Asian development. This is partly due to the statist orientation of that literature. Another issue concerning the study of the informal sector is definitions. Two general types of definitions exist - one focusing on functional attributes (e.g., small sizes and labor-intensive operations) and the other focusing on the extralegal status of the informal sector. In this study, I adopt the latter focus and refer the informal sector to economic activities that operate outside formal legal and financial institutions. According to this view, sizes and degrees of complexity are not defining characteristics of the informal sector. For general discussions about definitions, see Chickering and Salahdine (1991), Jenkins (1988). and Rakowski(1994).

2. The Economist (November 6, 1993). p. 37.

3. See Lin (1991) for an extensive bibliography on Chinese sources.

4. Market interlinkage refers to arrangements in which two parties are involved in two or more market exchanges simultaneously (see Flora and Yotopoulos, 1991).

5. As will be discussed in the next section, most trade credit transactions are facilitated by the use of postdated checks.
6. For further details about various forms of rotating credit associations, see Huang (1983) and Shen (1984).

7. For further details about the operation and scale of these and other informal credit arrangements, see Biggs (1991) and Peng and Chang (1985).

8. The Taiwanese government has attempted to solve the problem partly from within the formal sector by establishing banks specialized in serving small and medium enterprises and various loan guarantee programs. As indicated in several studies, these efforts have reached only a small number of the targeted firms (Yang and Hsio. 1993).

9. It is customary in Taiwan to use one's personal name chop, instead of signature, to endorse checks.

10. See Shea (1992), Table 2. The data are based on annual surveys conducted by the Central Bank of China. Borrowings from informal credit markets include those from other enterprises and households.

11. The Central Bank of China, Flow of Funds in Taiwan District. The Republic of China (1965-1991).

12. The Central Bank of China, Financial Statistics Monthly: Taiwan District, The Republic of China (March i\$93). 


\section{REFERENCES}

Adams. Dale W. and J. D. Von Pishke. "Microenterprise Credit Programs: Deja Vu." World Development. Vol. 20. No. 10(1992). pp. 1463-1470.

Adams. Dale W. and Delbert A. Fitchett (Eds). Informal Finance in Low-Income Countries (Boulder, CO: Westview Press. 1992).

Amsden. Alice M. (Ed.). "Special Section on The World Bank's The East Asian Miracle: Economic Growth and Public Policy." World Development. Vol. 22, No. 4 (1994). pp. 615-670.

Amsden, Alice M. . Asia's Next Giant: South Korea and Late Industrialization (New York, NY: Oxford University Press, 1989).

Biggs, Tyler S.. "Heterogeneous Firms and Efficient Financial Intermediation in Taiwan," in Michael Roemer and Christine Jones (Eds.). Markets in Developing Countries: Parallel. Fragmented, and Black (San Francisco, CA: ICS Press, 1991).

Braverman, Avishay and J. Luis Guasch. "Administrative Failures in Rural Credit Programs," in Karla Hoff. Avishay Braverman and Joseph E. Stiglitz (Eds.), The Economics of Rural Organization: Theory, Practice, and Policy (New York, NY: Oxford University Press. 1993).

Central Bank of China. "Financial Statistics Monthly" (Taipei: Economic Research Dept., Central Bank of China, various issues).

Central Bank of China, "Flow of funds in Taiwan District" (Taipei: Economic Research Dept., Central Bank of China, various years).

Chandavarkar, Anand, "Of Finance and Development: Neglected and Unsettled Questions," World Development, Vol. 20, No. 1 (1992). pp. 133-142.

Chen, Elaine, "The Chinese road to riches: Rotating credit association." Sinorama (September 1993), pp. 36-43.

Cheng, Tun-jen. "Guarding the commanding heights: The state as banker in Taiwan," in Stephen Haggard, Chung $\mathbf{H}$. Lee and Sylvia Maxfield (Eds.), The Politics of Finance in Developing Countries (Ithaca. NY: Cornell University Press, 1993).

Chickering. A. Lawrence and Mohamed Salahdine (Eds), The Silent Revolution: The Informal Sector in Five Asian and Near Eastern Countries (San Francisco, CA: ICS Press, 1991).

Christensen, Garry, "The limits to informal financial intermediation." World Development. Vol. 21. No. 5 (1993). pp. 721-731.

Coleman, James S., "The rational reconstruction of society," American Sociological Review, Vol. 58, No. 1 (1993), pp. 1-15.

de Soto, Hemando, The Other Path: The Invisible Revolution in the Third World (New York, NY: Harper \& Row. 1989).

de Soto, Hernando, "Constraints on people: The origins of underground economies and limits to their growth," in Jerrry Jenkins (Ed.), Beyond the Informal Sector: Including the Excluded in Developing Countries (San Francisco, CA: ICS Press, 1988).

The Economist, "Fear of finance: A survey of the world economy" (September 19. 1992).

Effros, Robert C. "The problem of postdated checks in the Republic of China." International Monetary Fund Staff
Papers. Vol. 18. No. 1 (1971). pp. 113-135

Emery. Robert F.. The Money Markers of Developing East Asia (New York. NY: Praeger. 1991).

Floro. Sagrario L. and Pan A. Yotopoulos. Informal Credit Markets and the New Institutional Economics: The Case of Philippine Agriculture (Boulder, CO: Westview Press. 1991).

Fry. Maxwell J.. Money. Interest and Banking in Economic Development (Baltimore. MD: The Johns Hopkins University Press. 1988).

Ghate, Prabhu. Informal Finance: Some Findings From Asia (New York. NY: Oxford University Press. 1992).

Gereffi. Gary and Donald L. Wyman (Eds). Manufacturing Miracles: Paths of Industrialization in Latin America and East Asia (Princeton, NJ: Princeton University Press. 1990).

Haggard, Stephan, Pathways from the Periphery: The Politics of Growth in the Newly Industrializing Countries (Ithaca. NY: Cornell University Press. 1990).

Hamilton. Gary G. and Nicole Woolsey Biggart, "Market, culture, and authority: A comparative analysis of management and organization in the Far East," American Journal of Sociology. Vol. 94, Supplement (1988) pp. S52-S94.

Hanke, Steve H. and Alan A. Walters, "Financial and capita markets in developing countries," in Steve H. Hanke and Alan A. Walters (Eds). Capital Markets and Development (San Francisco, CA: ICS Press. 1991).

Hoff, Karla and Joseph E. Stiglitz, "Imperfect information and rural credit markets: Puzzles and policy perspectives." in Karla Hoff, Avishay Braverman, and Joseph E. Stigliz (Eds.), The Economics of Rural Organization: Theory, Practice, and Policy (New York. NY: Oxford University Press, 1993).

Hoff, Karla, Avishay Braverman and Joseph E. Stiglitz (Eds.), The Economics of Rural Organization: Theory, Practice, and Policy (New York, NY: Oxford University Press, 1993).

Huang, Yung-Jen et al.. Problems of Underground Finance in Taiwan (Taichung: Center for Research and Training on Local Finance. 1983. in Chinese).

Islam, Iyanatul, "Political Economy and East Asia Economic Development," Asian-Pacific Economic Literature, Vol. 6. No. 2(1992), pp. 69-101.

Jenkins, Jerry (Ed.). Beyond the Informal Sector: Including the Excluded in Developing Countries (San Francisco, CA: ICS Press, 1988).

Lin, Chung-Hsiung et al.. A Study on Preventing and Controlling Underground Financial Activities (Taipei: Research, Development, and Evaluation Committee, Executive Yuan, 1991, in Chinese).

McKinnon, Ronald I. Money and Capital in Economic Development (Washington. DC: The Brookings Institution. 1973).

Peng, Pai-Hsien and S. H. Chang. "Financial channels for informal finance in Taiwan," Bank of Taiwan Quarterly, Vol. 36, No. 3 (1985), pp. 165-205, in Chinese.

Rakowski, Cathy A., "Convergence and divergence in the informal sector debate: A focus on Latin America 1984-92," World Development. Vol. 22, No. 4 (1994), pp. 501-516. 
Ranis. Gustav and Syed Akhtar Mahmood. The Political Economy of Development Policy Change (Oxford: Blackwell, 1992).

Roemer. Michael and Christine Jones, Markets in Developing Countries: Parallel. Fragmented, and Black (San Francisco. CA: ICS Press. 1991).

Shea. Jia-Dong, 'The welfare effects of financial liberalization under market segmentation - With special reference to Taiwan." Discussion Paper (Taipei: Institute of Economics. Academia Sinica. 1992).

Shea. Jia-Dong. "Financial development in Taiwan: A macro analysis." Paper presented at the Conference on Financial Development in Japan. Korea and Taiwan (Taipei: Institute of Economics, Academia Sinica. 1990).

Shea, Jia-Dong and Ping-Sing Kuo, "The allocative efficiency of banks' loanable funds in Taiwan," in Proceedings of the Conference on Financial Development in Taiwan (Taipei: Institute of Economics, Academia Sinica, 1984. in Chinese).

Shea, Jia-Dong and Tzung-Ta Yen, "Comparative experience of financial reforms in Taiwan and Korea: Implications for mainland China." Discussion Paper (Taipei: Institute of Economics. Academia Sinica. 1991).
Shen, Ying-Ming, A Study of Underground Finance (Taipei: Ministry of Finance, 1984, in Chinese).

Stiglitz, Joseph E.. "Markets, market failures, and development." American Economic Review. Vol. 79. No. 2 (1989a). pp 197-203.

Stiglitz. Joseph E.. "Financial markets and development." Oxford Review of Economic Policy, Vol. 5. No. 4 (1989b), pp. 55-68.

Stiglitz. Joseph E. and Andrew Weiss. "Credit rationing in markets with imperfect information." American Economic Review. Vol. 73. No. 5 (1981). pp. 912-927.

Yang. Ya-Hui and Hsuan I. I. Hsio. "An analysis of financial intermediation of medium and small enterprises," Taiwan: Community Financial Journal, Vol. 26 (March 1993). pp. 101-144. in Chinese.

Wade, Robert, Governing the Market: Economic Theory and the Role of Government in East Asia Industrialization (Princeton, NJ: Princeton University Press, 1990).

World Bank, The East Asian Miracle: Economic Growth and Public Policy (New York, NY: Oxford University Press. 1993).

World Bank. Financial Systems and Development (Washington. DC: The World Bank, 1990). 